\title{
Memory Controversies in Post-Genocide Rwanda: Implications for Peacebuilding
}

Elisabeth King

Follow this and additional works at: https://digitalcommons.usf.edu/gsp

\section{Recommended Citation}

King, Elisabeth (2010) "Memory Controversies in Post-Genocide Rwanda: Implications for Peacebuilding," Genocide Studies and Prevention: An International Journal: Vol. 5: Iss. 3: Article 6.

Available at: https://digitalcommons.usf.edu/gsp/vol5/iss3/6

This Articles is brought to you for free and open access by the Open Access Journals at Digital Commons @ University of South Florida. It has been accepted for inclusion in Genocide Studies and Prevention: An International Journal by an authorized editor of Digital Commons @ University of South Florida. For more information, please contact digitalcommons@usf.edu. 


\title{
Memory Controversies in Post-Genocide Rwanda: Implications for Peacebuilding
}

\author{
Elisabeth King \\ Postdoctoral Research Fellow, Earth Institute, \\ Columbia University
}

\begin{abstract}
Intrastate wars and genocides result in devastating losses and leave deep and lasting scars on those who survive. Making space for civilians to share their experiences of violence and to have them publicly acknowledged-especially by their own governments - can be important parts of (re)knitting the social fabric. This article focuses on the experiences of ordinary Rwandans during and after their country's civil war and genocide. It is centered on excerpts from a series of field interviews and highlights Rwandans' memories in their own words. This article contrasts this cross-section of civilian narratives with the official memories of violence that the national government disseminates through memorials and schools. The central argument is that, in order to legitimate its rule, the Rwandan government selectively highlights some memories of violence, and represses others, and that this is likely to hinder sustainable peace.
\end{abstract}

Key words: Rwanda, genocide, memory, acknowledgment, textbook, museum, reconciliation

Intrastate wars and genocides result in devastating losses and leave deep and lasting scars on those who survive. Moreover, in the aftermath, survivors must often live alongside former enemies and continue to reside where they experienced stateperpetrated violence. As a consequence, making space for civilians to share their experiences of violence and to have those experiences publicly acknowledgedespecially by their own governments-can be important parts of (re)knitting the social fabric. Unacknowledged wounds can present an obstacle to peacebuilding in both present and future generations.

Some key locations for state acknowledgment of experiences of violence include memorials, museums, and narratives in textbooks. Yet these locations are inadequately scrutinized and often considered to be part of the "soft cultural sphere" on the outskirts of power and politics. In contrast, I argue that selecting which civilian memories of violence to include and which to exclude in these sites is a political process that has important implications for "hard" politics—for the success of peacebuilding and future security.

This article focuses on the experiences of ordinary Rwandans during and after their country's civil war and genocide. It includes excerpts from field interviews and highlights Rwandans' memories in their own words. This article contrasts this crosssection of civilian narratives with the official memories of violence that the national government disseminates through memorials and schools. There are two central arguments. First, in order to legitimate its rule, the Rwandan government selectively highlights some civilian memories of violence, and represses others. Second, failing to acknowledge important memories hinders meaningful peacebuilding.

Elisabeth King, "Memory Controversies in Post-Genocide Rwanda: Implications for Peacebuilding," Genocide Studies and Prevention 5, 3 (December 2010): 293-309. (C) 2010 Genocide Studies and Prevention. doi:10.3138/gsp.5.3.293 
The first part of this article briefly reviews the concept of acknowledgment and examines its importance from the perspectives of academic literature, international organizations, and survivors. The second part turns to Rwanda, first elaborating on research methods, then exploring five types of civilian memories of violence, explaining how and why some are acknowledged, while others are left out. The third part elaborates on the implications for reconciliation, justice, and democracy.

\section{Acknowledging Civilian Memories of Violence}

Acknowledgment-meaning recognizing, admitting, or owning something and accepting the authority of the claims of others-is a key concept in the study and practice of post-conflict peacebuilding and conflict prevention. ${ }^{1}$ Acknowledgment in the aftermath of violent conflict includes civilians' experiences, as well as perpetrators' accountability for crimes. This article focuses primarily on the former, but the two overlap. It also focuses on official, national acknowledgment, but unofficial local and interpersonal processes of acknowledgment, as well as international acknowledgment, are also important.

Acknowledgment is widely considered a necessary part of post-violence societal recovery. In the peacebuilding literature, acknowledgment is argued to be important for reconciliation and the restoration of relationships, for transitional justice, and for building open, inclusive, and legitimate political institutions. ${ }^{2}$ In cases of genocide in particular, acknowledgment is also crucial to counteract the denial that often follows. ${ }^{3}$

The importance of acknowledgment is also commonly recognized by international organizations. United Nations' standards "call attention to the duty to remember." The Basic Principles and Guidelines on the Right to a Remedy and Reparation for Victims of Gross Violations of International Human Rights Law and Serious Violations of International Humanitarian Law, adopted by the General Assembly, include "commemorations and tributes to the victims" among the reparation duties of states, as well as a "public apology including acknowledgment of the facts and acceptance of responsibility." 4 This duty to remember was embraced in both the South African and Sierra Leonean Truth and Reconciliation Commissions, wherein recommendations included not only individual reparations, but community and symbolic measures such as the establishment of memorials and commemoration ceremonies. ${ }^{5}$

Most importantly, acknowledgment is often important to victims. A survey of survivors of violence in eleven countries as different as Afghanistan, Cambodia, Kosovo, and Sudan found that acknowledging experiences through memorialization was considered a key form of state reparation for violence. ${ }^{6}$ A central part of acknowledgment is that victims be satisfied with the response they receive. ${ }^{7}$

Nonetheless, a desire for acknowledgment may vary from case to case, across time, and from individual to individual. Hayner writes that "in Mozambique the accepted, though largely unstated, belief was 'the less we dwell on the past, the more likely reconciliation will be." "8 Hayner recalls "a palpable sense in Mozambique that if you talked about the war, it might come back."9 Shaw argues that reconciliation in Sierra Leone may also be served by silence. She writes that in northern Sierra Leone in particular, where social forgetting stands at the heart of established processes of reintegration and healing for child and adult ex-combatants, "speaking of the war in public often undermines these processes, and many believe it encourages violence." 10 There is no cookie-cutter model for post-conflict peacebuilding, and moreover, no standard way to best acknowledge civilian memories of violence. What may be appropriate in one case may not fit another. 
Yet, if one accepts the recurrent importance of acknowledging civilians' memories of violence, an important question arises: Whose stories to tell? While ours has been called "the era of testimony," 11 governments make unequal space for different memories of violence. Some memorials, for example, have been criticized for including too much; many Peruvians protested the "Eye that Cries" memorial for including the names of forty-one Shining Path guerillas massacred in a prison in $1994 .^{12}$ Not enough inclusion can also be problematic; Robben Island, the prime site of remembrance in post-apartheid South Africa, is criticized for its exclusion of the memories of victims and activists not associated with the current government, the African National Congress. ${ }^{13}$ The same types of controversies arise in regards to textbooks. In post-war Bosnia, textbooks are now published in Croat, Serb, and Bosniak versions, and include and exclude vastly different narratives. ${ }^{14}$ Minow suggests that the challenge for peacebuilding is "to seek a route between too much memory and too much forgetting." 15 In exploring this route, this article challenges collective memory as a singular concept.

\section{Research Methods in Rwanda}

This article draws on fieldwork conducted in Rwanda in 2006 to investigate the complex relationship between formal schooling on one hand, and violent conflict and peacebuilding on the other. The core fieldwork consisted of approximately seventy, one-on-one open-ended interviews with Rwandans. While not directly the topic of research, many Rwandans wanted to share their memories of violence. These included narratives that would be publicly acceptable, and many that would not. Below, this article recounts relatively long excerpts of several stories in an effort to both learn from, and to humbly acknowledge, these important memories. ${ }^{16}$

Those who experience violence are often considered "the most authentic bearers of truth about the past." 17 At the same time, interviewees have a number of reasons to only selectively tell their stories, and testimonies are filtered through historical memory. ${ }^{18}$ As Kalyvas notes, "there is compelling evidence that eyewitnesses of criminal (and other) events are systematically wrong about substantial parts of the events they are called to describe." 19 The stories recounted below derive from unverified individual testimony, but the validity of all of these types of narratives has been substantiated by other research and evidence.

This article contrasts various civilian memories of violence with the narratives portrayed at the Kigali Memorial Centre (Gisozi), ${ }^{20}$ Rwanda's main genocide memorial, and in the only existing primary school civics and social studies textbooks. ${ }^{21}$ Museums are particularly dense sites of memory where acknowledgment and the lack thereof come head to head. They are "a major area, in which politics, sensibilities, and folklore mingle." 22 The Kigali Memorial Centre is particularly important in Rwanda, serving as the main national memorial and the sole memorial with explicit narration. ${ }^{23}$ The Memorial Centre plans to add a traveling component with the aim that $90 \%$ of the Rwandan population is exposed to its messages. ${ }^{24}$ The Gisozi memorial has been subject to at least two recent grenade attacks, illustrating this site as one of symbolic significance and contention. ${ }^{25}$ School textbooks are also particularly important as they portray the "commonplaces of historical thinking of a certain place and time." ${ }^{26}$ In Rwanda, there has been a moratorium on teaching history since the genocide. The civics and social studies texts thus represent the state of teaching at this time and foreshadow how further curriculum is likely to develop. 


\section{Civilian Memories of Violence versus National Acknowledgment in Rwanda}

Rwanda descended into civil war in 1990 when the Rwandan Patriotic Front (RPF), a group of mostly Tutsi exiles who had fled Rwanda to Uganda in 1959, began an armed invasion against the Hutu government of Rwanda. While a peace and powersharing agreement was reached in Arusha in 1993, the accord did not hold. In April of 1994, genocide began, ending only three months later with approximately 800,000 Rwandans dead, including at least 500,000 Tutsi. ${ }^{27}$ The targets were civilians, as were more than $90 \%$ of casualties. ${ }^{28}$ A 1996 report of the United Nations Special Rapporteur on Rwanda estimated that between 250,000 and 500,000 Rwandan women and girls had been raped. ${ }^{29}$ Countless others, Tutsi and Hutu, male and female, young and old, were tortured or maimed before being left for dead by their fellow, particularly Hutu, Rwandans. Indeed, a significant proportion of the population participated in the killing. The military victory of the RPF brought the genocide to an end and the RPF remains the government of Rwanda today.

While this article refers to Hutu and Tutsi throughout, public ethnic identification is outlawed in post-genocide Rwanda, except in certain contexts. Ethnicity remains, nonetheless, a salient category for many Rwandans. At the same time, social differentiation is much more complex than it often appears and this article aims to highlight the variety of experiences within and across Hutu and Tutsi groups during and after violence in Rwanda.

The narratives below are thus categorized by ethnic group and level of national recognition, but this is an oversimplification. Other markers, such as class and region of provenance, are also important to one's position in Rwandan society. Moreover, the categories are neither static, nor black and white. During the genocide, for example, the same Rwandans often played different roles concomitantly; some Hutu, for instance, participated in killing, yet saved the lives of Tutsi close to them. ${ }^{30}$ Therefore, while five main genres of civilian memories of violence are discussed below-recognized Tutsi memories, somewhat recognized Hutu memories, unrecognized Hutu memories, unrecognized Tutsi memories, unrecognized memories of ethnically mixed Rwandans-these categories are neither watertight nor exhaustive.

\section{Recognized Tutsi Memories}

The first type of narrative that emerged during interviews involves memories from Tutsi survivors of genocide. When asked about his family's experience with genocide, one Tutsi youth recounted:

So, it happened [the genocide] when my mother, my little brother, and my little sister-who was still in my mother's stomach, she wasn't born yet-were there [his father was in Burundi]. So, in the end, my mother and I were here in Rwanda and we tried to escape to [hide in] the wells. The first time, someone tried to intervene but was told to do his job [elsewhere], to machete some, and so he turned away. And the second time too, it was by God, they were going to throw water in and someone came, and told them that they had a job to do, and they left again. So, we left that area where we lived, my mother and I. She carried my little brother on her back, and me, she took my hand, and we left for [name removed]. So there was a place that people were being taken, but instead of staying there where we were supposed to stay, there where they were massacring a lot, a multitude of people, we continued. We arrived in a place, in another region, and it is there that we were able to escape. In fact, you know diapers, that you put on a child to leave his waste? We hid two 
potatoes in there, sweet potatoes, so that we could survive. Me, my mother, and my little brother, we ate for a week. And then, we had a brother, my uncle, who was a soldier of the saviors. So, since we had a brother who was a soldier for the RPF, and he saw that we were there, he took us and put us in a little security. We spent one month, two months, then when the war was over we returned [home].

But, in the meantime, while we weren't there, my mother's family, just about everyone was kccchhh [makes the sound and actions of getting chopped in the neck with a machete]. In the end, my mother's family ... no one was left. Just the co-wife. Yup, the co-wife was left, and that's our family. And that's our experience of the genocide.

I guess I was traumatized, yes, seeing someone machete in front of you. I was a little traumatized. Once, someone was shot right in front of me when I was there. They killed him. I was there. They [the killer] had to walk in front of me and I felt something rise inside me. My mother wasn't near me; I don't know where she was hiding. So I said to myself, "Is it true that someone can lose their head like that?" I was shocked. ${ }^{31}$

At the Kigali Memorial Centre one encounters similar stories. There are panels, stills, and clips dedicated to survivors' narratives. The memorial Web site also includes ten survivors' testimonies with the intention to expand to a larger database. Each person's story is heart-wrenching and defies description. The memories, however, share some commonalities. Each tells of horrific specifics of violence, such as Anne-Marie Bucyana, whose husband and child were killed while she was raped, or Emmanuel Mugenzira, who was shot in the head and left for dead like the rest of his family. They talk of fleeing to churches, United Nations camps, and into the mountains. They also share the emotional trauma of life in post-genocide Rwanda. For example, as Dancilla Nyirabazungu recounts, "I clean, I garden, I separate the clothes from the bones left on the church floor." 32 Half of the narratives refer to the causes of genocide being grounded in dehumanization and discrimination against Tutsi by the previous regime. All of the testimonies explicitly or implicitly suggest a Tutsi voice. ${ }^{33}$

The type of narrative recounted by the teenage boy above fits in with the historical panels at Kigali Memorial Centre, with primary school textbooks, and with the RPF's version of history. The panels at Gisozi, for example, present precolonial Rwanda as a golden age: "This has been our home for centuries. We are one people. We speak one language. We have one history." 34 It blames divisions between Rwandans on the colonial powers: "We have lived in peace for many centuries, but now the divide between us had begun." The panels explain that when Rwanda gained independence it "became a highly centralized, repressive state with a single party system" wherein "the regime was characterized by the persecution and ethnic cleansing of Tutsi." The Gisozi narrative explains that the "Path to a 'Final Solution"" began long before the 1994 genocide when "over 700,000 Tutsis were exiled from our country between 1959 [and] 1973" and explains that "genocide was rehearsed." The panels note that "Rwandan Tutsis had been fleeing for more than a generation." They report that when President Habyarimana's plane was shot down, "genocide was instant," "it was genocide from the first day," and that "no Tutsi was exempt" since "the death lists had been pre-prepared in advance." It explains that "any Tutsi who tried to pass [a roadblock] was humiliated, beaten, mutilated, murdered, raped and dumped by the roadside." With panels that explain the specifics of torture, the Kigali Memorial Centre notes that "Rwanda had turned into a nation of brutal, sadistic merciless killers and of innocent victims, overnight." While decrying 
the failure of an international response, the panels note that the RPF moved forward "in an attempt to gain control and to stop the genocide." The narrative presented in the civics and social studies textbooks is very similar. ${ }^{35}$

Narratives of Tutsi genocide survivors that support the RPF's policies and views of history are the most prominent genre of narrative in post-genocide Rwanda. It is crucially important that these stories are told. Having a record of survivors' testimonies helps avoid potential negation of the genocide. ${ }^{36}$ Victims and survivors deserve respect and acknowledgment. There are also significant potential benefits of giving and hearing testimonies of violence. The process of telling one's story, and it being acknowledged through listening and empathy, can contribute to healing. ${ }^{37}$ Indeed, as argued above, recognizing and commemorating victims and crimes can be crucial steps in reconciliation and part of a transitional justice process. Learning about the experiences, as well as the causes and consequences of genocide, may also be important for its future prevention. ${ }^{38}$

At the same time, many survivors remain unsatisfied with the space that they are granted for their memories and the political uses to which they are being put. As Doughty reports, "many survivors feel that repatriated refugees [including much of the government] came in late, know nothing of genocide, and are reaping more benefits of Rwanda's post-genocide reconstruction" than they are. ${ }^{39}$ The RPF is instrumentalizing these memories of violence and using the genocide as a political tool. ${ }^{40}$ It bases its legitimacy at home and abroad on having stopped the genocide and thus having the moral high ground over the international community, as well as other Rwandans. Moreover, by emphasizing the long-term persecution of Tutsi dating to 1959, the government consolidates Tutsi that were in and outside of Rwanda at the time of the genocide into a single "survivor" group. Therefore, in addition to the importance of these narratives for acknowledgment and peacebuilding, promulgating Tutsi survivors' memories is central to the government's maintenance of power.

\section{Somewhat Recognized Hutu Memories}

Second, there is also a public place for the narratives of Rwandans who helped hide those trying to escape genocide. One former Rwandan army soldier, a Hutu, shared his story:

During the war, as I was a soldier, I hid many people, Tutsis that were threatened. As a soldier, I was strong, I commanded, I hid many people. Instead of killing them, or stealing their money, I kept their money and I hid them in my home ... After the fall of Kigali, I left Kigali and I went outside of the country. I came back here in 2002. When I arrived, it was them that welcomed me and gave me everything. Now I am brother and sister with them. So it is for this reason that I wanted to tell you this story. Now, I can tell my children, or my brothers, that killing isn't good, that using an opportunity to do bad is not good. If we write stories that during the war, instead of killing people, people also hid others like this, and that after the war, one is proud to be with the Tutsis that he hid, if we teach this history that shows reality and the truth, the path created for our children will produce something [better.] ${ }^{41}$

At the Kigali Genocide Centre, there are panels dedicated to this genre of civilian memories under the heading of "Resistance to Genocide." The panels note that "resistance took many forms. The RPF led the political and armed resistance to genocide. Members of moderate wings of different political parties made passionate calls for resistance. Some of the victims organized resistance to the killings. A 
number of Hutus and others hid targeted victims sometimes at the risk of their own lives." 42 After some short excerpts on resistance by Tutsi survivors in specific locations, the panels turn to feature six named rescuers, including short testimonies, mostly from survivors rather than rescuers themselves. The ethnicity of the rescuers is never explicit, although the Tutsi identity of the victims is often mentioned. Four of the ten survivor stories presented on the Gisozi memorial Web site, and discussed above, refer to people that helped them hide and escape. Nonetheless, the museum also features a videotaped testimonial where a survivor suggests that only $5 \%$ of the Hutu population was innocent. ${ }^{43}$

Primary civic education textbooks mention rescuers, this time specifying Hutu, but only briefly: "A Hutu deemed a traitor-for having hidden one or several Tutsi-was forced by the killers to kill them himself. When he did not do so, he was killed along with the members of his family." 44 Students recounted that they also learn about Agathe Uwiligiyimana, the former moderate Hutu prime minister, who is celebrated on National Heroes Day. Uwiligiyimana, who would likely have issued a radio call for calm the morning after Habyarimana's plane was shot down, was among the first killed during the genocide. ${ }^{45}$

While there is space in Rwanda for stories that recognize the positive role of some Rwandans, and particularly Hutu rescuers, during the genocide, this already narrow space is further narrowing. For example, there has been great controversy surrounding the actions and statements of Paul Rusesabagina, the Hutu temporary manager of the Hotel des Mille Collines, credited with saving up to thousands of lives during the genocide (and best known as the basis for the main character of the movie Hotel Rwanda). The Rwandan government and newspapers have charged him with having "a self-promotion agenda while distorting Rwanda's history and spreading negative propaganda against the current government" and with advancing "outrageous assertions and dirty campaigns." 46 The government has also accused Rusesabagina of denying genocide. Acts of Hutu "heroism" are also frequently received with suspicion at local gacaca courts. ${ }^{47}$

The former soldier cited above felt that more stories like his needed to be shared, a sentiment echoed by other interviewees. He emphasized that the roles of different groups in Rwanda's genocide are more nuanced than the government usually makes them appear. Indeed, the dominant narrative often polarizes TutsiHutu as survivor-perpetrator; the panel at Gisozi, mentioned above, notes "Rwanda had turned into a nation of brutal, sadistic merciless killers and of innocent victims, overnight" providing only two role options.

\section{Unrecognized Hutu Memories}

Third, while there is space, however limited, for Hutu rescuers of the genocide, and mention of "Hutu moderates" killed during the genocide (by insinuation by other Hutu), there is no public space in Rwanda for Hutu memories of violence perpetrated by the RPF. Indeed, saying that there are "unpunished RPF crimes" is equated with negation of genocide and may classify as the punishable offense of "genocide ideology."48

Yet reports indicate that the RPF committed widespread killings during the civil war (1990-1993) and during the genocide. Since 1994, the RPF has engaged in killing and other violations of human rights in two wars in the Congo (1996-1997, 1998-2003), as well as in ongoing operations, and in massacres in Rwanda, such as at the Kibeho camp for the internally displaced in April 1995. ${ }^{49}$ 
In response to a question about her family's losses to violence, a female Hutu youth replied:

Me? My father, my family. Except my grandmother and my older sister that were not killed in the war. This was when the RPF came by here. Yes. Now we have no means to continue without my father. We are no longer valued. ${ }^{50}$

Witness also this representative statement from an elderly Hutu woman from Northern Rwanda:

The other history that we have to teach [besides the government version disseminated at memorials, ingando re-education camps, and schools]. For example, I lost threequarters of my family during the war. There's my mother who died during the war. There is my daughter, her child that died. I say in my house there was my father who died, there was my little sister, my brother-in-law, my grandchildren. My brother-in-law and his wife were killed. But we don't have the right to say we lost people. There are orphans of the genocide, widows of the genocide, everything of the genocide. That's it. That creates a lot of conflicts. But we keep quiet. Us [Hutu], we can't say anything. I can't say anything because if I say it they will put me in prison, or punish me in another way, but they also have to give the ability to people to speak and to say what they think. ${ }^{51}$

The civics textbook notes that during the genocide of 1994, "more than one million Tutsi and moderate Hutu" were killed, but it is silent to other violence experienced by Hutu. ${ }^{52}$ The social studies textbook is similar, acknowledging the killing of "Hutu moderates who did not follow the government's extreme policies." 53 As a Hutu youth said, in response to a question about what schools teach about the war from 1990-1993 and genocide,

On the subject of the war and the genocide, they tell us how it developed. For the most part, they taught about genocide. They don't say [anything] about the war. They teach us about the genocide only. ${ }^{54}$

Similarly, at the Kigali Memorial Centre, the panels note that "Hutus who did not comply [help kill Tutsi] were threatened with death. A number of Hutus who did not subscribe to the genocidal ideology, as well as those who tried to protect Tutsis were persecuted and killed." 55 Yet, as in the civics textbook, "of the reprisal massacres of Hutus by the Tutsi rebels there is not a word. Not surprising, perhaps, since the rebels now run the country." A representative of the Aegis Trust, who helped design the museum, claims that this was his decision, not the government's: "in this society at this time it's akin to Britain in 1945 talking about the bombing of Dresden as a war crime." 56

The reality is more complicated. The British and American air forces that carried out the bombing of Dresden and were key players in ending World War II did not have to govern post-war Germany, nor live alongside German survivors of the bombing or German perpetrators of war. In Rwanda, the Rwandan Patriotic Front ended the genocide through military victory and still leads the country today.

The Rwandan government has made important progress on a number of fronts and is often praised for its role in Rwanda's political stability and economic growth. Indeed, the image of stability and progress of President Paul Kagame's government dominates international reporting and much of academia as well. ${ }^{57}$ Yet Rwanda today is much closer to authoritarianism and dictatorship than to democracy, and there is increasing concentration of power around a small group of former Tutsi exiles from Uganda. Many Rwandans experience censorship and self-censorship, and 
fear being charged with the vague offenses of "divisionism" and "genocide ideology," which increasingly seems to mean simply disagreeing with the government. 58

Several Hutu interviewees felt left out of mourning and lamented that they are not allowed space for their stories and memories of violence. They consider themselves to be victims, but their victimhood remains unacknowledged by the state. Vidal makes a similar argument in reference to commemorations, arguing that Hutu survivors have had their right to publicly suffer and mourn "confiscated." 59 Burnet notes that while Hutu and Tutsi received joint recognition as victims of the genocide at the first annual commemoration, subsequent commemorations have illustrated that Tutsi hold a "monopoly on suffering" in Rwanda. ${ }^{60}$ From early references to the "Rwandan genocide," the government has moved since about 2008 to calling the events of 1994 the "Tutsi genocide." 61

Furthermore, public space for the first two types of narratives-those of Tutsi survivors and Hutu rescuers-paired with the exclusion of Hutu memories of violence and mention only of the death of Hutu moderates, implies that those that do not fall into these first two categories are génocidaires. The middle ground between survivor-perpetrator categories is eclipsed and the RPF often hides outlawed ethnic distinctions behind these new categories.

\title{
Unrecognized Tutsi Memories
}

Fourth, there are also Tutsi memories of war and genocide that do not make it into the public sphere. One female Tutsi youth shared her story:

\begin{abstract}
So, when the war started, we were there, at home. That night we heard life falling and we panicked. Our father counseled us to stay in the hallways, because of the bars [reinforcements] so that we didn't have any accidents. We spent two weeks like that in the house, and our neighbors, those with means, were leaving. They were leaving even if we had really been friends with them before. And after a time, it was military guys that came and took us to Byumba because it was there, beside Uganda where there was no war. Well before, they [the military men, RPF] lived in Uganda, it's from there that they came in [to Rwanda], it's there that there are borders.
\end{abstract}

So we left for Byumba on foot! From Kigali to Byumba on foot. Me, I was three years, four years old. I had a little brother who was a baby during the war. Well, finding food was a problem. So, he was sick during the war. So we left, we went to Byumba. We were in a school. Well there, the situation, I don't know how [to describe it]. There was no food. There was cholera and sickness everywhere. I remember when we arrived, there was a swimming pool dripping with blood. It was completely red. We were thirsty. So we drank it. Well, it was terrible.

My little brother was still sick. So, we looked for all methods to go to Uganda. They could not accept that my father go with us [he was a medical doctor]. So we left with my mother, my brothers, and my sister. He had to stay. And also, there were the soldiers. There were things that they did. They wanted us to go get all of the boys so that they could go fight. It was the RPF that came asking for boys. So my [older] brother had to hide, so that they wouldn't find him. ${ }^{62}$

The last part of this girl's memory - that the RPF was clandestinely recruiting boys and was feared by some-is contrary to the way the RPF would like to be perceived. Nonetheless, research shows that many Tutsi feared RPF soldiers. ${ }^{63}$ In contrast, the RPF sees itself as the savior of Rwandans and as the representative of genocide victims. The type of civilian memory presented above is thus not part of the 
memories of violence that are acknowledged by the RPF government, nor noted at the Kigali Memorial Centre, nor in textbooks.

There have been public denunciations by Ibuka, the largest survivor organization, that the government sometimes ill-represents survivor interests and even exploits their suffering for its own ends. ${ }^{64}$ As Tutsi genocide survivor Innocent Rwililiza recounted to journalist Jean Hatzfeld,

\begin{abstract}
Basically, it's the Tutsis from abroad, those of the former diaspora, who are running the show. These Tutsis suffered in exile and returned after the killings to reclaim houses, buy the most cows, start up new businesses.... They govern the country. And the survivors, they wind up frustrated, under a crippling inhibition, and they murmur.... Being powerless to voice one's anger, sadness, and longing for what is lost, and unable to tell one's whole story for fear of offending a Hutu or annoying the authorities-this inability to reveal one's heart is sheer torture. I say this sincerely: Survivors have no opportunity to express their true private feelings in public and to ask for a comforting little compensation. ${ }^{65}$
\end{abstract}

Other survivors told Hatzfeld that they feel they cannot speak publicly about their memories to anyone but other survivors, except when they are called upon during ceremonies, gacaca, and mourning week. ${ }^{66}$ In short, Tutsi with memories inconsistent with the way the RPF wishes to be perceived are excluded from public space, and some Tutsi survivors feel that their ability to speak out and to be acknowledged is constrained more broadly.

\title{
Unrecognized Memories of Ethnically Mixed Rwandans
}

Finally, Rwandans of mixed ethnic background are also often restricted in terms of public acknowledgment of their memories. As one teenage boy with a Hutu mother and Tutsi father replied, when asked if he had lost anyone in genocide,

During the genocide, it's hard to say, because, ummm, those that belonged to the family of my father were affected. But they were Tutsis and they were exiled [before the genocide]. Unfortunately, it is my maternal grandmother and grandfather that died. They told us that it was the RPF army that shot them....67

When asked whether she felt acknowledged by the government, a Tutsi teenager with parents of two different ethnicities said,

I am a child alone in the world. No father, no mother, no brothers, no sisters. I am alone. I am not able to be helped by the FARG [a government program to help genocide survivors pay for health care and school fees] because it is for children with Tutsi fathers and Tutsi mothers. But me, my mother was Tutsi, my father no. ${ }^{68}$

While the school textbooks say nothing of Rwandans with mixed ethnic heritage, the Gisozi memorial mentions only that "Hutu women in mixed marriages were raped as punishment" and that "Hutu and Tutsi women were forced to kill their own Tutsi children." 69

Rwandans with mixed ethnic background are often in a particularly difficult position given the post-genocide government's bipolar association of survivorperpetrator status with ethnicity. Burnet recounts the story of Séraphine, a Hutu, married to a Tutsi husband, who was repeatedly raped. "Despite Séraphine's emotional and physical suffering, she was not perceived as a survivor for two reasonsbecause she was Hutu and because her husband did not die. Furthermore, with the polarizing discourse in post-genocide Rwanda, because she was not a 'survivor,' Séraphine became classified, by default, as a perpetrator."70 


\section{Other}

There are many other genres of civilian narratives of violence that have not been discussed here. These include memories of violence of Twa Rwandans, narratives of repatriés who were not in the country in 1994 but who are sometimes falsely subsumed into the first category of Tutsi genocide survivors, and, of course, those that were killed and thus unable to share their stories.

In sum, in post-genocide Rwanda, civilians hold a multitude of different and nuanced memories of violence. Yet only some civilian memories of violence are acknowledged while others are repressed. The former are predominantly from Tutsi, and include some narratives from Hutu that helped rescue other Rwandans; the latter are from Hutu who have memories of violence perpetrated by the RPF, and also include Tutsi and ethnically mixed Rwandans whose memories contradict the narrative with which the RPF legitimates its position.

\section{Implications for Peacebuilding}

The selection and distortion of social memory for political interests, while understudied by scholars of conflict and peacebuilding, is frequent. It has long been recognized that the victors write history. Paradoxically, in Rwanda, the strong state structures that facilitated genocide remain and determine the representation of violence. However, the exclusion of certain memories of violence is unlikely to lead to meaningful peacebuilding in Rwanda. Many Rwandans' memories are inconsistent with public ones and there is friction between state discourses and personal narratives.

In terms of reconciliation, several Hutu Rwandans explained that by failing to recognize their pain and to acknowledge their mourning, it is difficult for them to relate to and to embrace the suffering of Tutsi Rwandans. As one Hutu participant at the first National Unity and Reconciliation Summit voiced, "we do not say it loud enough, but the question of Hutu memory is a prerequisite so that people can sit together and sincerely discuss the real problems of this country." 71 As one elderly Hutu man told me, "perhaps if there is reconciliation, things will be okay. But a real reconciliation, where people talk."72 A lack of acknowledgment is particularly pressing in Rwanda where Hutu and Tutsi in post-genocide Rwanda remain intermingled on the same hills.

Rwanda's Senate report on Genocide Ideology condemns as revisionist attempts to "vaguely acknowledg[e] genocide but, in the same breath, [try] to justify it through counter accusations in order to cleanse the real culprits of any responsibility." 73 In contrast, as Godobo-Madikizela suggests as she reflects on South Africa, "in societies trying to break the cycle of hatred and revenge, it is important to first acknowledge [emphasis added] as did the TRC, that human rights abuses were committed on both sides, and then to find an effective way of moving society forward." 74 Acknowledging a wider range of civilian memories need not invoke questions of moral equivalence or absolve responsibility for genocide.

By acknowledging only a select category of memories of violence, the government is failing to address and challenge the social cleavages and exclusion that characterized Rwanda's past and may be, moreover, fostering exclusion and social cleavages in the present. This is as true for Tutsi with memories inconsistent with the public narrative as it is for Hutu. This sense of exclusion could help lay the foundations for future intergroup conflict. Devine-Wright explains that memories of victimization harden boundaries between "us" and "them," and foster in-group cohesion and 
out-group derogation. Grievances surrounding unacknowledged, or unsettled, historical memories are likely to increase in intensity with time. Unacknowledged emotional (or physical) wounds could be powerful motivations for vengeance, including violence. ${ }^{75}$ In Rwanda, lack of acknowledgment of memories of members of the Hutu majority may be especially problematic.

In terms of justice, many Rwandans feel that by failing to acknowledge their memories of violence, the RPF is reigning with impunity. ${ }^{76}$ This could also hinder a sustainable peace. Falconer argues that reconciliation of memories, an important part of peacebuilding, includes both accepting responsibility for the past actions of one's group and acknowledging the history of the other group to learn from its experiences. ${ }^{77}$ As Cole argues, while schools and the narratives that they teach have been largely neglected by the transitional justice literature, they "should have a place at the table." 78 In relation to justice in Rwanda more broadly, Longman argues that the post-genocide justice system highlights certain human rights violations, contributing to the erasure of others. He contends that trials disseminate the $\mathrm{RPF}$ narrative and ignore parts of the past that do not fit. ${ }^{79}$ Acknowledging only some memories of violence and selectively applying accountability negates the rule of law. The government's monopoly on memory may be considered victors' justice.

The Rwandan government espouses the importance of some tenets of democracy by holding elections, but at the same time engages in antidemocratic practices. For instance, the quality of democracy depends on the participation of its citizens; but the acknowledgment of only some civilian memories involves great exclusion and coercion. Many Rwandans do not feel free to share their opinions or memories in public. The Rwandan character today, explained one female Hutu youth, "it's hiding things. We don't forget, but we hide. Yes, it's difficult, but we try. It is in our character. We don't show you that we hate you. It's difficult. Even if you come to my house, I show you that there is no problem between you and I. But the problem is in my heart. We do not have the habit of opening ourselves, of showing on the exterior what we are thinking on the interior." 80 Others were more explicit about the repression and censorship that they experience. One elderly Hutu woman said that "Rwandans have become liars. We can't say anything because they'll imprison us or kill us." 81 Freedom House International ranks Rwanda as "not free." 82 In the end, neglecting or more actively repressing, certain memories can be both a symptom of, and catalyst for, other forms of repression. ${ }^{83}$

\section{Conclusion}

Scholars, international organizations, and victims alike consider acknowledgment of memories of violence an important element of (re)building the social fabric. Since each post-conflict and post-genocide context differs enormously, there is no recipe for acknowledgment in sites like memorials or textbooks. Yet, selecting which memories to include and which to exclude is a common challenge with important consequences. This article suggests that memorials and textbooks are not on the margins of power, as some suggest; there is significant power and important implications vested in the ability to choose how to represent past violence.

In Rwanda, the Kigali Memorial Centre and primary school textbooks, key sites of the official historical record, prioritize only some memories. They exclude the memories of violence of numerous segments of the population and interviews reveal a number of stories that contradict official accounts. Hutu who have memories of violence perpetrated by the RPF, as well as Tutsi, and ethnically mixed Rwandans 
whose memories contradict the narrative upon which the RPF legitimates its position, are silenced. This exclusion of many Rwandans' memories is likely to hinder reconciliation, justice, and democracy and undermine durable peace.

\section{Acknowledgments}

The author gratefully acknowledges the assistance, advice, and support of research assistants Noel Anderson and Chelsea Fairbank, four anonymous reviewers, participants at the International Studies Association 2009 meeting in New York City and the 2009 Development and Democracy in Post-Conflict African Nations conference at the University of Illinois at Chicago, as well as the Earth Institute at Columbia University, the Canadian Social Sciences and Humanities Research Council and the Canadian Consortium on Human Security. Most of all, the author wishes to thank the many Rwandans who made this research possible.

\section{Notes}

1. While there are often many important differences in causes, consequences, and responses to genocide and other forms of violent conflict, there are also many similar challenges in the aftermath, including acknowledgment. The conflict prevention and peacebuilding literature is thus useful in this sense.

2. Hizkias Assefa, "Reconciliation," in Peace-Building: A Field Guide, ed. Luc Reychler and Thania Paffenholz (Boulder: Lynne Rienner, 2001); Patrick Devine-Wright, "A Theoretical Overview of Memory and Conflict," in The Role of Memory in Ethnic Conflict, ed. Ed Cairns and Michael D. Roe (New York: Palgrave Macmillan, 2003); Lynn Graybill and Kimberley Lanegran, "Truth, Justice, and Reconciliation in Africa," African Studies Quarterly 8, 1 (2004), http://web.africa.ufl.edu/asq/v8/v8i1a1.htm (accessed 2 April 2010); Priscilla B. Hayner, Unspeakable Truths: Confronting State Terror and Atrocity (New York: Routledge, 2001); Ho-Won Jeong, "Peacebuilding: Conceptual and Policy Issues," in Approaches to Peacebuilding, ed. Ho-Won Jeong (Hampshire: Palgrave Macmillan, 2002); Ho-Won Jeong and Charles Lerche, "Reconciliation: Contexts and Consequences," in Approaches to Peacebuilding, ed. Ho-Won Jeong (Hampshire: Palgrave Macmillan, 2002); Wendy Lambourne, "Transitional Justice and Peacebuilding after Mass Violence," The International Journal of Transitional Justice 3, 1 (2009): 311-37; John Paul Lederach, Building Peace: Sustainable Reconciliation in Divided Societies (Washington, DC: United States Institute of Peace Press, 1997); Kimberly A. Maynard, "Rebuilding Community: Psychosocial Healing, Reintegration, and Reconciliation at the Grassroots Level," in Rebuilding Societies after Civil War: Critical Roles for International Assistance, ed. Krishna Kumar (Boulder: Lynne Rienner, 1997); Joanna Quinn, “The Politics of Acknowledgement: Truth Commissions in Uganda and Haiti" (PhD diss., Political Science, McMaster University, 2003); and Joanna Quinn, "Social Reconstruction in Uganda: The Role of Customary Mechanisms in Transitional Justice," Human Rights Review 8 (2007): 389-407.

3. Gregory H. Stanton, "The 8 Stages of Genocide" (Washington, DC: Genocide Watch, 1998).

4. Basic Principles and Guidelines on the Right to a Remedy and Reparation for Victims of Gross Violations of International Human Rights Law and Serious Violations of International Humanitarian Law: Resolution / adopted by the General Assembly, UN General Assembly, UN Doc. A/RES/60/147 (21 March 2006).

5. Beth Goldblatt, "Evaluating the Gender Content of Reparations: Lessons from South Africa," in What Happened to the Women? Gender and Reparations for Human Rights Violations, ed. Ruth Rubio-Marín, 48-91 (New York: Social Science Research Council, 2006), 70; Jamesina King, "Gender and Reparations in Sierra Leone: The Wounds of War Remain Open," in What Happened to the Women? Gender and Reparations for Human Rights Violations, ed. Ruth Rubio-Marín, 246-83 (New York: Social Science Research Council, 2006). 
6. Acknowledgment is second only to financial compensation. Ernesto Kiza, Corene Rathgeber, and Holger C. Rohne, Victims of War: An Empirical Study of War Victimization and Victims' Attitudes Toward Addressing Atrocities (Hamburg, Germany: Hamburg Institute for Social Research, 2006).

7. Graybill and Lanegran, "Truth, Justice, and Reconciliation in Africa."

8. Hayner, Unspeakable Truths: Confronting State Terror and Atrocity, 187.

9. Ibid, 189.

10. Rosalind Shaw, Rethinking Truth and Reconciliation Commissions: Lessons from Sierra Leone (Washington, DC: United States Institute of Peace, 2005), 1.

11. Shoshana Felman and Dori Laub, Testimony: Crises of Witnessing in Literature, Psychoanalysis and History (New York: Routledge, 1992).

12. Sebastian Brett, Louis Bickford, Liz Sevenko, and Marcela Rios, "Memorialization and Democracy: State Policy and Civic Action" (paper presented at Memorialization and Democracy: State Policy and Civic Action, Santiago, Chile, 2007).

13. Ibid.

14. Mireal-Luminita Murgescu, "Rewriting School Textbooks as a Tool of Understanding and Stability," Journal of Southeast European and Black Sea Studies 2, 1 (2002): 90-104.

15. Martha Minow, Between Vengeance and Forgiveness: Facing History after Genocide and Mass Violence (Boston: Beacon Press, 1998), 118.

16. While in some contexts there are important nuances between the terms narrative, testimony, story, and memory, I use them interchangeably here.

17. Bain Attwood, "In the Age of Testimony: The Stolen Generations Narrative, 'Distance' and Public History," Public Culture 20, 1 (2008): 75-95, 78.

18. Elisabeth King, "From Data Problems to Data Points: Challenges and Opportunities of Research in Post-Genocide Rwanda," African Studies Review 52, 3 (2009): 127-48.

19. Stathis N. Kalyvas, The Logic of Violence in Civil War (New York: Cambridge University Press, 2006), 37.

20. The information from the Kigali Memorial Centre was collected during two personal visits and a third visit by a research assistant who copied all museum panels. The memorial centre Web site was also useful. See "Kigali Memorial Centre,"

www.kigalimemorialcentre.org (accessed 11 May 2009).

21. Emmanuel Bamusanire, Joseph Byiringiro, Augustine Munyakazi, and Johnson Ntagaramba, Primary Social Studies 4: Pupil's Book (Kigali: Macmillan Rwanda, 2006); Bamusanire, Byiringiro, Munyakazi, and Ntagaramba, Primary Social Studies 5: Pupil's Book (Kigali: Macmillan Rwanda, 2006); Bamusanire, Byiringiro, Munyakazi, and Ntagaramba, Primary Social Studies 6: Pupil's Book (Kigali: Macmillan Rwanda, 2006); Jeanne D’Arc Baranyizigiye, John Rutayisire, Méschac Bizimana, Clémentine Gafiligi, Marie Kankindi, and Yassini Maniraguha, A Guide to Civic Education: Life Skills for Rwanda Primary Schools, Upper Primary Level-P4-P5—P6 (Kigali: National Curriculum Development Centre, 2004).

22. Jacques Le Goff, History and Memory, trans. Steven Rendall and Elisabeth Claman (New York: Columbia University Press, 1992), 87.

23. As of a 2009 visit to Rwanda, the panels at Murambi Genocide Memorial, previously a second site recounting an explicit narrative, had been indefinitely removed.

24. Personal communication, 2009.

25. James Karuhanga, "Rwanda: One Injured in Grenade Attack on Gisozi Genocide Memorial," The New Times (16 April 2009), http://allafrica.com/stories/200904160257.html (accessed 11 May 2009); "Grenade Attack at Rwanda Genocide Memorial," Panapress (11 April 2008), http://en.afrik.com/article13161.html (accessed 11 May 2009).

26. Edward Herbert Dance, History the Betrayer: A Study in Bias (London: Hutchinson, 1960), 54.

27. Alison Des Forges, Leave None to Tell the Story (New York: Human Rights Watch, 1999).

28. United Nations Development Programme, Human Development Report 1997 (New York: Oxford University Press, 1997). 
29. Anne-Marie de Brouwer, Supranational Criminal Prosecution of Sexual Violence: The ICC and the Practice of the ICTY and the ICTR (Antwerp: Intersentia, 2005).

30. Des Forges, Leave None to Tell the Story, 11. Lee Ann Fujii, Killing Neighbors: Social Dimensions of Genocide in Rwanda (Ithaca, NY: Cornell University Press, 2009).

31. Interview, 14 February 2006. This and all subsequent quotations are the author's translation from the French.

32. Notes from visits to the Kigali Memorial Centre and from its Web site.

33. There are a number of further places where one can find survivors' memories of violence in their own words. For one of the first collections to include vivid descriptions of the atrocities inflicted upon Tutsi victims in their own words, see African Rights, Rwanda, Death, Despair and Defiance (London: African Rights, 1994). In Rwanda: The State of Research (Online Encyclopedia of Mass Violence, 4 November 2007) http://www.massviolence.org/ Rwanda-The-State-of-Research (accessed 15 May 2009), René Lemarchand points to Yolande Mukagasana and Patrick May's La mort ne veut pas de moi, Mukagasana's Les blessures $d u$ silence, and Venuste Kayimahe's Témoignage d'un rescapé as important pieces of "witness literature." Browsing the Internet, one encounters "Voices of Rwanda" (VOR), an NGO dedicated exclusively to recording the testimonies of genocide survivors (http://www.voicesofrwanda.org); the Holocaust Memorial Day Trust (http://www.hmd. org.uk/resources/cat/3/); and Aegis Trust (http://www.aegistrust.org).

34. This paragraph is based on notes from visits to the Kigali Memorial Centre and from its Web site.

35. King, "From Data Problems to Data Points."

36. Lars Waldorf, "Revisiting Hotel Rwanda: Genocide Ideology, Reconciliation, and Rescuers," Journal of Genocide Research 11, 1 (2009): 101-25.

37. Graybill and Lanegran, "Truth, Justice, and Reconciliation in Africa"; Ervin Staub, "Justice, Healing and Reconciliation: How the People's Courts in Rwanda Can Promote Them," Peace and Conflict: Journal of Peace Psychology 10, 1 (2004): 25-32.

38. Minow, Between Vengeance and Forgiveness; Burcu Munyas, "Genocide in the Minds of Cambodian Youth: Transmitting (Hi)stories of Genocide to Second and Third Generations in Cambodia," Journal of Genocide Research 10 (2008): 413-39.

39. Kristin C. Doughty, "Commemoration and Narratives of Community Healing: Ten Years after the Rwandan Genocide," in Health Knowledge and Belief Systems in Africa, ed. T. Fayola and M. Heaton, 183-204 (Durham, NC: Carolina Academic Press, 2008), 198.

40. Jennie E. Burnet, "Whose Genocide? Whose Truth? Representations of Victim and Perpetrator in Rwanda," in Genocide: Truth, Memory, and Representation, ed. A.L. Hinton and K.L. O'Neill, 80-110 (Durham, NC: Duke University Press, 2009); Johan Pottier, Re-Imagining Rwanda: Conflict, Survival and Disinformation in the Late Twentieth Century (Cambridge: Cambridge University Press, 2002).

41. Interview, 28 January 2006.

42. Notes from visits to the Kigali Memorial Centre and its Web site.

43. Doughty, "Commemoration and Narratives of Community Healing," 196.

44. Baranyizigiye et al., A Guide to Civic Education, 36.

45. For other stories from Hutu rescuers, see Villia Jefremovas, "Acts of Human Kindness: Tutsi, Hutu and the Genocide," Issue: A Journal of Opinion 23, 2 (1995): 28-31.

46. Charles Mugabo, "Do Not Distort Rwanda's History," New Times, 30 August 2007; Mugabo, "Rusesabagina's Ill-Conceived Agenda," New Times, 26 September 2007. See also, Waldorf, "Revisiting Hotel Rwanda," 114-18.

47. Jennie E. Burnet, "The Injustice of Local Justice: Truth, Reconciliation, and Revenge in Rwanda," Genocide Studies and Prevention 3, 2 (2008): 173-93, 188.

48. Senate of Rwanda, Rwanda Genocide Ideology and Strategies for Its Eradication (Kigali: Rwanda Parliament, 2006), 17.

49. Des Forges, Leave None to Tell the Story; Nigel Eltringham, Accouting for Horror: PostGenocide Debates in Rwanda (London: Pluto Press, 2004); International Crisis Group, "Rwanda at the End of the Transition: A Necessary Political Liberalisation," in Africa 
Report (Nairobi: International Crisis Group, 2002); Filip Reyntjens, "Rwanda, Ten Years On: From Genocide to Dictatorship," African Affairs 103 (2004): 177-210.

50. Interview, 3 April 2006.

51. Interview, 21 March 2006.

52. Baranyizigiye, et al., A Guide to Civic Education, 36.

53. Bamusanire et al., Primary Social Studies 6: Pupil's Book, 61-62.

54. Interview, 3 April 2006. Public space in Rwanda is closed to nearly all Hutu narratives of violence. Yet, some published testimonies by Hutu are now being read internationally, such as Marie-Béatrice Umutesi's Surviving the Slaughter, which recounts her experience as a Hutu in Rwanda before and after the genocide, and in exile in the Congo thereafter (Madison: University of Wisconsin Press, 2004). In Rwanda: The State of Research, Lemarchand suggests that other narratives focusing on ethnic cleansing in the aftermath of genocide include Maurice Niwese, Le peuple rwandais un pied dans la tombe: Récit d'un réfugié étudiant, Philippe Mpayimana, Réfugiés rwandais: Entre marteau et enclume. Récit du calvaire au Zaire, 1996-1997, and Benoit Rugumaho, L'hécatombe des réfugiés rwandais dans l'ex-Zaire: Témoignage d'un survivant. These books may someday contribute to international acknowledgment of the violence perpetrated against Hutu, yet so far, the international community remains very complimentary of the current Rwandan government. Some change was underway as this article went to press. The UN had just released a major report documenting atrocities in the DR Congo, including those perpetrated by Rwandan forces. See: Democratic Republic of the Congo, 1993-2003: Report of the Mapping Exercise documenting the most serious violations of human rights and international humanitarian law committed within the territory of the Democratic Republic of the Congo between March 1993 and June 2003. (Geneva: United Nations Office of the High Commissioner for Human Rights, October 2010).

55. Notes from visits to the Kigali Memorial Centre and from its Web site.

56. Rory Carroll, "In Memory of Murder," The Guardian, 24 March 2004, http://www.guardian.co.uk/artanddesign/2004/mar/24/art.rwanda (accessed 2 April 2010).

57. Pottier, Re-Imagining Rwanda.

58. International Crisis Group, "Rwanda at the End of the Transition."

59. Claudine Vidal, "Les commémorations du génocide au Rwanda," Les Temps Modernes 613 (2001): 1-46, 46.

60. Burnet, "Whose Genocide? Whose Truth?" 87-88.

61. Waldorf, "Revisiting Hotel Rwanda," 104.

62. Interview, 11 February 2006.

63. Fujii, Killing Neighbors, 118.

64. Vidal, "Les commémorations du génocide au Rwanda," 44; Waldorf, "Revisiting Hotel Rwanda," 108.

65. Jean Hatzfeld, The Antelope's Strategy: Living in Rwanda after the Genocide (New York: Farrar, Straus and Giroux, 2009), 89-90.

66. Ibid., 82-83, 105.

67. Interview, 14 February 2006.

68. Interview, 4 March 2006.

69. Notes from visits to the Kigali Memorial Centre and from its Web site.

70. Burnet, "Whose Genocide? Whose Truth?" 90-91. For what Lemarchand (in Rwanda: The State of Research, 5) describes as "one of the most arresting and unbiased" survivor testimonies, by a Rwandan of mixed ethnic origins, see Edouard Kabagema, Carnage d'une nation: Genocide et massacres au Rwanda, 1994 (Paris: Editions L'Harmattan, 2002).

71. Quoted in Vidal, "Les commémorations du génocide au Rwanda," 46; author's translation.

72. Interview, 20 March 2006.

73. Senate of Rwanda, Rwanda Genocide Ideology and Strategies for Its Eradication, 18.

74. Quoted in James L. Gibson, Overcoming Apartheid: Can Truth Reconcile a Divided Nation? (New York: Russell Sage Foundation, 2004).

75. Patrick Devine-Wright, "A Theoretical Overview of Memory and Conflict," 14-15. 
76. See Eltringham, Accounting for Horror; Gérard Prunier, The Rwanda Crisis: History of a Genocide 1959-1994 (London: C. Hurst and Company, 1997).

77. Ed Cairns and Michael D. Roe, "Introduction: Why Memories in Conflict?" in The Role of Memory in Ethnic Conflict, ed. Ed Cairns and Michael D. Roe (New York: Palgrave Macmillan, 2003).

78. Elizabeth Cole, "Transitional Justice and the Reform of History Education," International Journal of Transitional Justice 1 (2007): 115-37, 120.

79. Timothy Longman, "Memory, Justice and Power in Post-Genocide Rwanda" (paper presented at the Meeting of the American Political Science Association, Philadelphia, 2006).

80. Interview, 14 March 2006.

81. Interview, 21 March 2006.

82. Freedom House International, Freedom in the World: Country Report: Rwanda (Washington, DC: FHI, 2009).

83. Brett et al., "Memorialization and Democracy," 20. 